Article

\title{
Tumor Microenvironment and Microvascular Density in Follicular Lymphoma
}

\author{
Roberto Tamma $^{1, *(\mathcal{C}}$, Giuseppe Ingravallo ${ }^{2}\left(\mathbb{D}\right.$, Tiziana Annese $^{1}\left(\mathbb{D}\right.$, Francesco Gaudio $^{3}$, Tommasina Perrone ${ }^{3}$, \\ Pellegrino Musto ${ }^{3}\left(\mathbb{D}\right.$, Giorgina Specchia $^{3}$ and Domenico Ribatti ${ }^{1, *(1)}$
}

1 Department of Basic Medical Sciences, Neurosciences, and Sensory Organs, University of Bari Medical School, Piazza G. Cesare 11, 70124 Bari, Italy; tiziana.annese@uniba.it

2 Department of Emergency and Transplantation, Pathology Section, University of Bari Medical School, 70124 Bari, Italy; giuseppe.ingravallo@uniba.it

3 Department of Emergency and Transplantation, Hematology Section, University of Bari Medical School, 70124 Bari, Italy; francesco.gaudio@uniba.it (F.G.); tommasina.perrone@policlinico.ba.it (T.P.); pellegrino.musto@uniba.it (P.M.); giorgina.specchia@uniba.it (G.S.)

* Correspondence: roberto.tamma@uniba.it (R.T.); domenico.ribatti@uniba.it (D.R.); Tel.: +39-080-5478323 (R.T); Fax: +39-080-5478310 (R.T.)

check for updates

Citation: Tamma, R.; Ingravallo, G.; Annese, T.; Gaudio, F.; Perrone, T.; Musto, P.; Specchia, G.; Ribatti, D. Tumor Microenvironment and Microvascular Density in Follicular Lymphoma. J. Clin. Med. 2022, 11 1257. https://doi.org/10.3390/ jcm11051257

Academic Editor: Thomas R. Chauncey

Received: 14 February 2022 Accepted: 23 February 2022 Published: 25 February 2022

Publisher's Note: MDPI stays neutral with regard to jurisdictional claims in published maps and institutional affiliations.

Copyright: (C) 2022 by the authors. Licensee MDPI, Basel, Switzerland. This article is an open access article distributed under the terms and conditions of the Creative Commons Attribution (CC BY) license (https:// creativecommons.org/licenses/by/ $4.0 /)$.

\begin{abstract}
Follicular lymphoma (FL) is a slowly progressive disease and constitutes the second most common non-Hodgkin lymphoma. Biological factors, such as the tumor microenvironment and the host response, are determinants in the outcome of FL but the experimental data about microenvironment and tumor cells in FL are variable and contradictory. In this morphometric study, we analyzed by immunohistochemistry the cellular components of the tumor microenvironment and correlated these data with the microvascular vascular density in three different grades of FL lymph node biopsies, comparing the results to healthy lymph node controls. The results indicated a significant increase in the number of $\mathrm{CD}^{+} 8^{+}$and $\mathrm{CD}_{163}{ }^{+}$macrophages in all three analyzed FL grades. Tryptase $^{+}$mast cells resulted in an increase only in grade 1 . PDL- $1^{+}$cells, CD4- and CD8-lymphocytes number results were reduced in FL samples. The higher number of CD34 ${ }^{+}$microvessels in the FL grades 1 and 2 of samples positively correlated with $\mathrm{CD} 68^{+}$and $\mathrm{CD} 163^{+}$cells, underlining the important angiogenic potential of this subset of macrophages.
\end{abstract}

Keywords: angiogenesis; follicular lymphoma; NHL; tumor microenvironment

\section{Introduction}

Follicular lymphoma (FL) is a slowly progressive disease belonging to B-cell nonHodgkin lymphomas (B-NHLs), constituting the second most common NHL. The median age is around 60 with a male to female ratio of 1:1.7. Usual sites of disease development principally include the lymph nodes, but may involve the spleen, bone marrow, peripheral blood, and gastrointestinal tract [1,2]. Its indolent progression leads to delayed diagnosis and consequently, a high percentage of patients present an advanced FL at the initial diagnosis. FL affected patients show a variable outcome in absence of treatment, including spontaneous remissions reported in about $15 \%$ of the patients [3].

FL results from the clonal expansion of germinal center (GC) B cells, even if malignant transformation is initiated during early B-cell development in the bone marrow, by aberrant repair failure of $\mathrm{V}(\mathrm{D}) \mathrm{J}$ recombination. The resulting $\mathrm{t}(14 ; 18)$ translocation promotes high expression of the anti-apoptotic protein BCL2 [4], providing a survival advantage to B cells during GC reaction, wherein BCL2 is normally actively repressed by the GC-specific transcriptional machinery $[5,6]$.

According to the World Health Organization (WHO) classification, FL includes grade 1-3 (low grade to high grade) depending on the percentage of centroblasts: grade 1 (follicular small cleaved): 0-5 centroblasts/high-power field (HPF), grade 2 (follicular mixed): 
6-15 centroblasts/HPF, and grade 3 (follicular large cell): > 15 centroblasts/HPF (grade $3 \mathrm{~A}$-centrocytes present, grade $3 \mathrm{~B}$ - solid sheets of centroblasts). It is important to clinically differentiate grades $1 / 2$ vs. grade 3 [2,7]. In half of FL patients, a histological transformation to aggressive lymphoma such as diffuse large B cell lymphoma (DLBCL) occurs, inducing a worse outcome [8]. The FL treatments are variable and include watchful waiting and the anti-CD20 antibody as monotherapy, a combination of chemotherapy, radiotherapy, and radioimmunotherapy, or chemotherapy at a high dosage followed by hematopoietic stem cell transplantation. Promising results have emerged with the anti-CD20 antibody and chemotherapy association [9].

Although it is well documented that genetic changes are involved in FL initiation and progression, the interaction between the immune microenvironment and FL tumor cells is acquiring increasing importance [10-12]. In FL patients, neoplastic follicles maintain an architecture similar to the normal lymph nodes in which B cells remain dependent on cellular and molecular events that contribute to the normal GC and include stromal cells, T-follicular helper cells (Tfh), T-follicular regulatory cells (TFRs), and follicular dendritic cells (FDCs), normally found in the lymphoid follicles [13].

The prognosis of FL remains heterogeneous, and this negatively contributes to the programming of an effective clinical design. Many prognostic factors have been considered allowing the creation of the FL International Prognostic Index (FLIPI) to develop a more accurate prognostic index. FLIPIs are based on clinical factors but they ignore biological factors, such as the tumor microenvironment (TME) and the host response [14,15]. It is well known that all the steps following tumorigenesis including the growth, progression, and metastatic process, are strongly influenced by the tumor microenvironment [16,17]. TME is a complex environment surrounding the cancer cells that includes cellular and extracellular components and a vascular network [18] which are also involved in the determination of therapeutic efficacy [19].

Scientific works highlight the importance of the TME composition in determining the pathogenesis of lymphoma and the complex interplay between the different cells of TME. Tumor associated macrophages (TAMs) promote immunosuppression inhibiting the recruitment and activity of T cells [20]. Moreover, TAMs influence tumor progression by regulating angiogenesis [21]. Mast cells are also involved in tumor progression [22,23] through protumoral, stimulating angiogenesis and anti-tumoral responses and recruiting other immune cells [24]. CD8 ${ }^{+} \mathrm{T}$ cells have been reported in FL TME with an inconstant number and are mainly located in the perifollicular regions of the lymph node $[25,26]$. Furthermore, $\mathrm{CD}^{+} \mathrm{T}$ cell counts are lower than $\mathrm{CD} 4^{+} \mathrm{T}$ cells. FL tumor cells modulate gene expression of CD8 ${ }^{+}$ and $\mathrm{CD} 4^{+}$cells [27], and the survival of FL tumor cells is dependent on surrounding CD4 ${ }^{+}$ $\mathrm{T}$ cells $[28,29]$. Moreover, $\mathrm{CD} 4^{+} \mathrm{T}$ cells ${ }^{\prime}$ heterogeneity in FL and their distribution play an independent role in prognosis and permitting integration into prognostic scores to improve risk stratification [30]. Finally, $\mathrm{CD} 4^{+}$and $\mathrm{CD}^{+}$cells mediate the anti-angiogenic effect of IL-12 [31] and express IFN $\gamma$ which inhibits the proliferation of endothelial cells and induces the expression of CXCL9/10/11 in TAMs with an angiostatic effect [32,33].

TME is enabling the discovery of targeted therapies and providing data to improve the prediction of tumor progression. For example, PD-1/PD-L1 controls excessive immunity of cytotoxic $\mathrm{T}$ cells leading to the failure of $\mathrm{T}$ cell immunity. Tumor cells express PDL1 [34], and as a consequence of PD-1/PD-L1 pathway inhibition, T cells become active and exert more pronounced antitumor effects by rescuing exhausted $\mathrm{T}$ cells $[35,36]$. In B-cell lymphoma, the PD-1/PD-L1 blockade therapy has shown positive effects promoting the formation of "hot" immune-inflamed TME [37,38]. Combination treatment, for example, with chimeric antigen receptor $\mathrm{T}$ cells (CAR-T) and nivolumab, or PD-1 inhibition with concomitant radiotherapy can then be used [39].

Pembrolizumab is the only FDA-approved agent for use with R/R B-NHL (i.e., PMBL) patients [40]. Nivolumab was evaluated in patients with relapsed and refractory B-NHL and a phase I study of 54 patients with NHL, including $10 \mathrm{FL}, 11$ DLBCL, 10 other B cell lymphomas, 13 peripheral T cell lymphoma (PTCL), and 5 other T cell lymphomas [41]. 
The highest ORR was observed among FL patients, followed by DLBCL. In the phase I study of ipilimumab in patients with R/R B-NHL, 18 patients were enrolled [42]. Two patients had clinical responses; the ORR was low, only $11 \%$. One with DLBCL achieved a durable CR lasting > 31 months, and another with FL had a PR lasting 19 months. In a phase I study, patients with R/R FL received nivolumab (1 or $3 \mathrm{mg} / \mathrm{kg}$, every 2 weeks) [43].

The data in the literature about the interactions between the microenvironment and tumor cells in FL are variable and contradictory although it is thought that TME in FL acts in two directions, one supporting tumor growth and survival and the other suppressing the anti-tumoral immune response. Immunohistochemical analysis on FL tissue samples is bringing out important information on FL TME cell populations as well as their spatial distribution in the tissue.

In this work, we analyzed, by an immunohistochemical approach, the lymph node biopsies derived from FL patients at grades 1,2, and 3A, at first diagnosis and focused our attention on the quantification of tumor microenvironmental cells, including macrophages, mast cells, $\mathrm{CD}^{+}$and $\mathrm{CD}^{+}$lymphocytes, and PD-L1 positive cells and the microvessel density in the different groups of patients comparing them with normal lymph nodes.

\section{Materials and Methods}

\subsection{Patients}

This retrospective study included bioptic specimens derived from 60 lymph nodes of FL patients of 1, 2, and 3A grade at first diagnosis (Table 1) and 20 healthy lymph nodes used as control. The 60 patients and the 20 controls have been subdivided into FL1, FL2, FL3 groups according to the FL grade and CTRL group. The samples were collected from the archive of the Section of Pathology of the University of Bari School of Medicine between 2019 and 2021. All procedures were in accordance with the ethical standards of the responsible committee on human experimentation (institutional and national) and with the Helsinki Declaration of 1964 and later versions; signed informed consent from individual patients were obtained to conduct the study.

Table 1. Main clinical features of FL patient.

\begin{tabular}{ccc}
\hline & FL Patients & \\
\hline Gender (\%) & Male & 60 \\
& Female & 60 \\
Age (years) & Median & $39-80$ \\
\hline Ki67\% & Range & 27 \\
\hline \multirow{2}{*}{ Stage (number) } & Ave & $10-70$ \\
\hline \multirow{2}{*}{ First diagnosis (\%) } & Range & 20 \\
& I & 20 \\
\hline \multirow{2}{*}{ Extranodal sites $(\%)$} & II & 20 \\
\hline & IIIA & 100 \\
& I & 100 \\
& II & 100 \\
\hline
\end{tabular}

\subsection{CD4, CD8, CD68, CD163, Tryptase, CD34, and PDL-1 Immunohistochemistry}

Serial histological sections of $4 \mathrm{~mm}$ thickness, collected on poly-L-lysine-coated slides (Sigma Chemical, St. Louis, MO, USA), were deparaffinized. The sections were rehydrated in a xylene-graded alcohol scale and then rinsed for $10 \mathrm{~min}$ in $0.1 \mathrm{M}$ PBS. Sections were pretreated with sodium citrate ( $\mathrm{pH}$ 6.1) solution (DAKO, Glostrup, Denmark) for antigen retrieval for $30 \mathrm{~min}$ at $98{ }^{\circ} \mathrm{C}$ and then incubated with mouse monoclonal anti-CD4 (DAKO, Glostrup, Denmark), mouse monoclonal anti-CD8 (DAKO, Glostrup, Denmark), 
mouse monoclonal anti-CD68 (DAKO, Glostrup, Denmark), mouse monoclonal anti-CD163 (DAKO, Glostrup, Denmark), mouse monoclonal anti-Tryptase (DAKO, Glostrup, Denmark), mouse monoclonal anti-CD34 (DAKO, Glostrup, Denmark), and mouse monoclonal anti-pd-11 (DAKO, Glostrup, Denmark) diluted 1:50, 1:50 1:100, 1:100, 1:100, 1:100, and 1:50, respectively. Thereafter, the sections were counterstained with Mayer hematoxylin and mounted in a synthetic medium. Specific pre-immune serum (DAKO), replacing the primary antibodies, served as a negative control. Ten sections from each experimental group were scanned using the whole-slide morphometric analysis scanning platform Aperio Scanscope CS (Leica Biosystems, Nussloch, Germany). All the slides were scanned at the maximum available magnification $(40 \times)$ and stored as digital high-resolution images on the workstation associated with the instrument. Digital slides were inspected with Aperio ImageScope v.11 software (Leica Biosystems, Nussloch, Germany) at $20 \times$ magnification, and 10 fields with an equal area were selected for the analysis at $40 \times$ magnification. The protein expression was assessed with the Positive Pixel Count algorithm embedded in the Aperio ImageScope software and reported as positivity percentage, defined as the number of positively stained pixels on the total pixels in the image.

\subsection{Statistical Analysis}

Data related to the three experimental groups, FL1, FL2, and FL3, are reported as means \pm SE. Newman-Keuls multiple comparisons post-test was used to compare all treatment groups after one-way ANOVA. The Graph Pad Prism 5.0 statistical package (GraphPad Software, San Diego, CA, USA) was used for analyses and the limit for statistical significance was set at $p<0.05$. Correlation analysis was performed with the Spearman nonparametric correlation test.

\section{Results}

\subsection{CD68, CD163, and Tryptase Immunohistochemistry}

Follicular lymphoma and CTRL tissue samples were immune stained for CD68 (Figure 1), CD163 (Figure 2) and tryptase (Figure 3) to evaluate total macrophages, M2 macrophages, and mast cells, respectively. Morphometric analysis showed significantly increased numbers of $\mathrm{CD}^{+}$and $\mathrm{CD}^{+} 63^{+}$cells in all the grades of FL samples (CD68: FL1 $(22.4 \pm 0.9 \%)$, FL2 (18 $\pm 0.4 \%)$, and FL3 (20 $\pm 0.46 \%)$; CD163: FL1 (14.8 $\pm 1.1 \%)$, FL2 $(18 \pm 1 \%)$, and FL3 (14.7 $\pm 0.4 \%$ ) as compared to the CTRL group (CD68: $11 \pm 1.6 \%$; CD163: $2.9 \pm 0.6 \%$ ). Regarding tryptase ${ }^{+}$mast cells, we observed their significant increase in the grade 1 of FL samples (tryptase: FL1 $(6.1 \pm 0.8 \%)$, FL2 $(1.7 \pm 0.4 \%)$, and FL3 $(0.91 \pm 0.41 \%)$ ) as compared to the CTRL group (CTRL: $2.5 \pm 1.4 \%$ ).

\subsection{CD4 and CD8 Immunohistochemistry}

FL samples and CTRL specimens were immune stained for CD4 and CD8 to evaluate $\mathrm{CD}^{+}$(Figure 4) and $\mathrm{CD}^{+}$cells (Figure 5). Morphometric analysis indicated the significant reduction of $\mathrm{CD}^{+}$cell number in all the three FL grades $\left(\mathrm{CD}^{+}\right.$: FL1 $(11.8 \pm 3.2 \%)$, FL2 $(4.6 \pm 1.2 \%)$, and FL3 $(13 \pm 1.9 \%))$ with respect to the CTRL $(34 \pm 6.3 \%)$. CD8 ${ }^{+}$cells number underwent a slight (not significant) increase in FL1 and a significant reduction in the other FL groups $\left(\mathrm{CD}^{+}:\right.$FL1 $(15.3 \pm 3.9 \%)$, FL2 $(8 \pm 1.1 \%)$, FL3 $\left.(8.4 \pm 1.2 \%)\right)$ with respect to the CTRL $(13 \pm 1.3 \%)$.

\subsection{CD34 and PD-L1 Immunohistochemistry}

FL samples groups and CTRL specimens were immune stained for CD34 (Figure 6), and PDL-1 (Figure 7) to estimate the microvessel density and the number of PDL-1 expressing cells, respectively. Morphometric analysis showed the significant increase of $\mathrm{CD}^{+} 4^{+}$at grades 1 and 2 of FL samples (CD34: FL1 (8.6 $\left.\pm 0.4 \%\right)$, FOLL2 (8.2 $\left.\pm 0.54 \%\right)$; FL3 $(2.63 \pm 0.54 \%)$ ) as compared to the CTRL group (CD34: $2.2 \pm 0.5 \%)$. PDL- $1^{+}$cells, on the other hand, underwent a significant, strong reduction in FL groups (PD-L1 ${ }^{+}$: FL1 $(0.1 \pm 0.02 \%)$, FL2 $(0.3 \pm 0.07 \%)$, FL3 $(1 \pm 0.2 \%))$ respect to the healthy CTRL $(7.3 \pm 0.98 \%)$. 


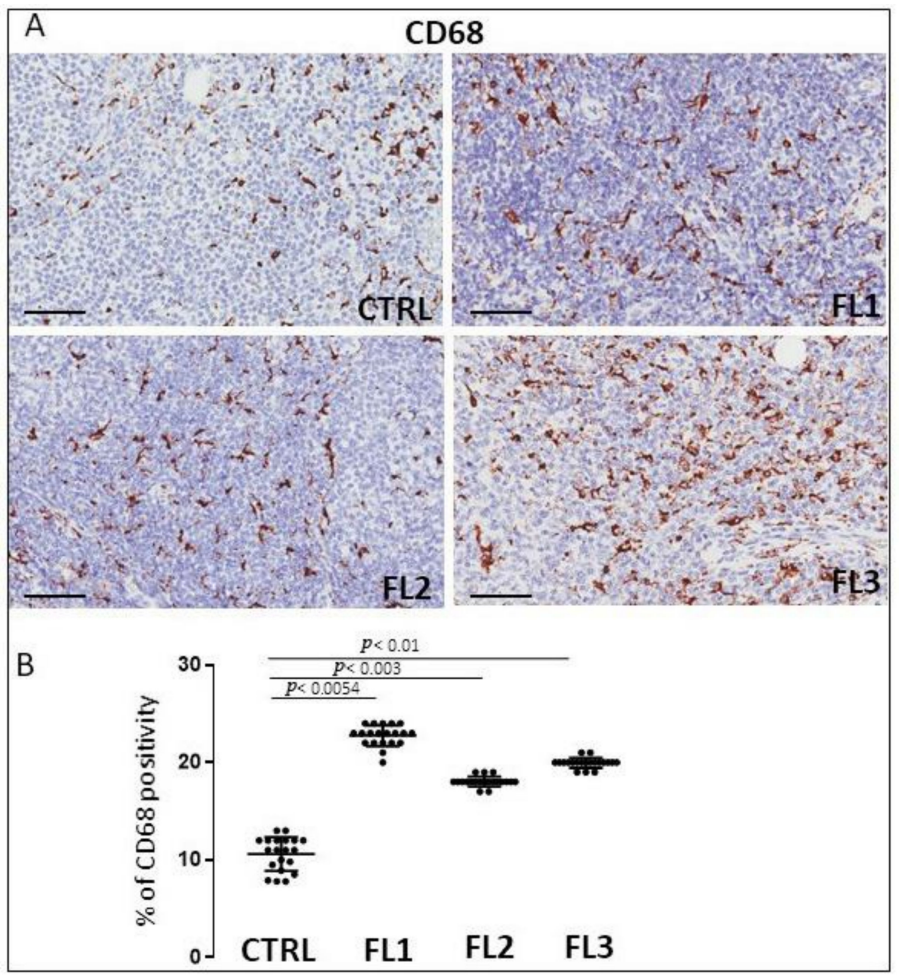

Figure 1. Immunohistochemical staining for CD68 in FL grade1 (FL1), FL grade2 (FL2), and FL grade 3 (FL3) and control samples (CTRL) (A). Scale bar: $60 \mu \mathrm{m}$ (A). Morphometric analysis indicates the percentage of CD68 positivity in FL and CTRL samples (B).

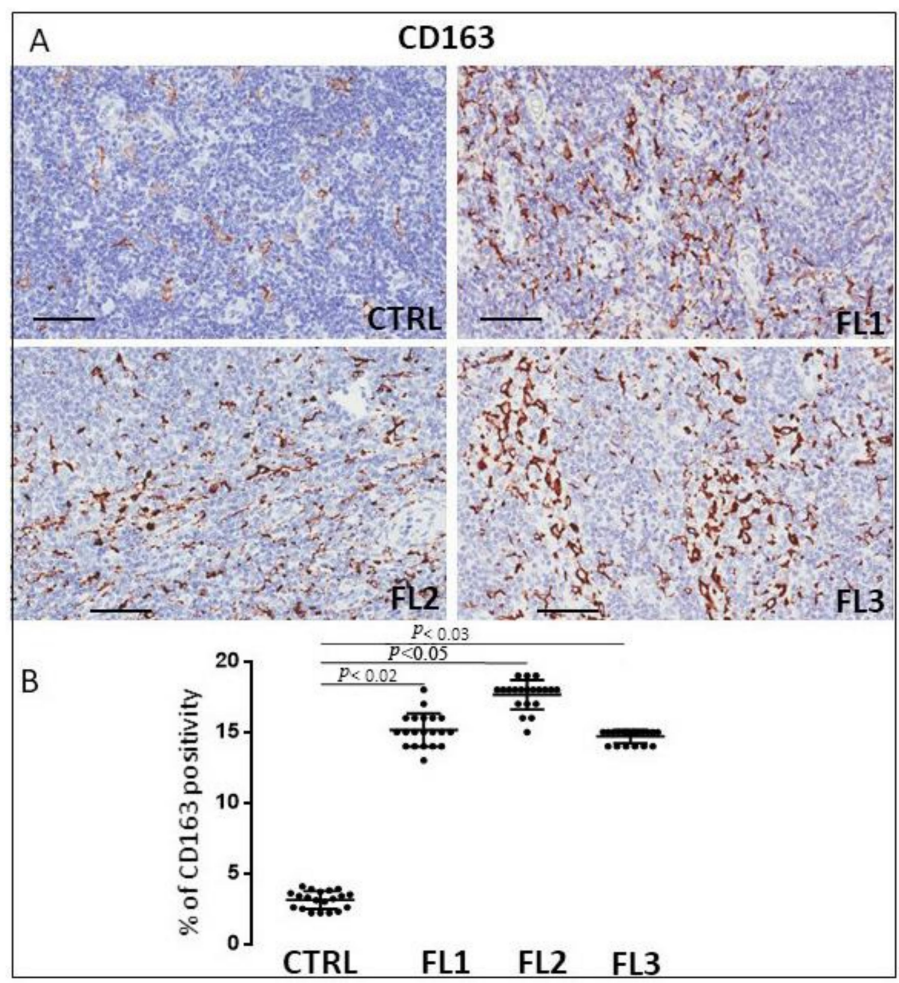

Figure 2. Immunohistochemical staining for CD163 in FL grade1 (FL1), FL grade2 (FL2), and FL grade 3 (FL3) and control samples (CTRL). Scale bar: $60 \mu \mathrm{m}$ (A). Morphometric analysis indicates the percentage of CD163 positivity in FL and CTRL samples (B). 


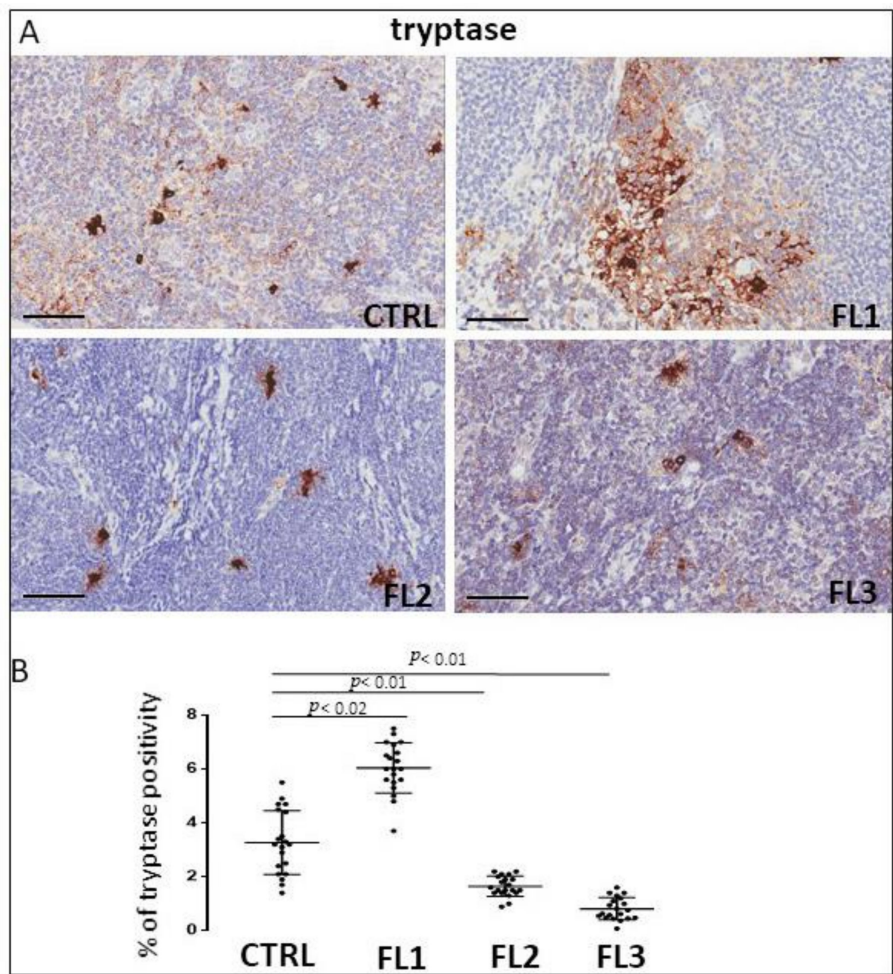

Figure 3. Immunohistochemical staining for tryptase in FL grade1 (FL1), FL grade2 (FL2), and FL grade 3 (FL3) and control samples (CTRL). Scale bar: $60 \mu \mathrm{m}$ (A). Morphometric analysis indicates the percentage of tryptase ${ }^{+}$mast cells in FL and CTRL samples (B).

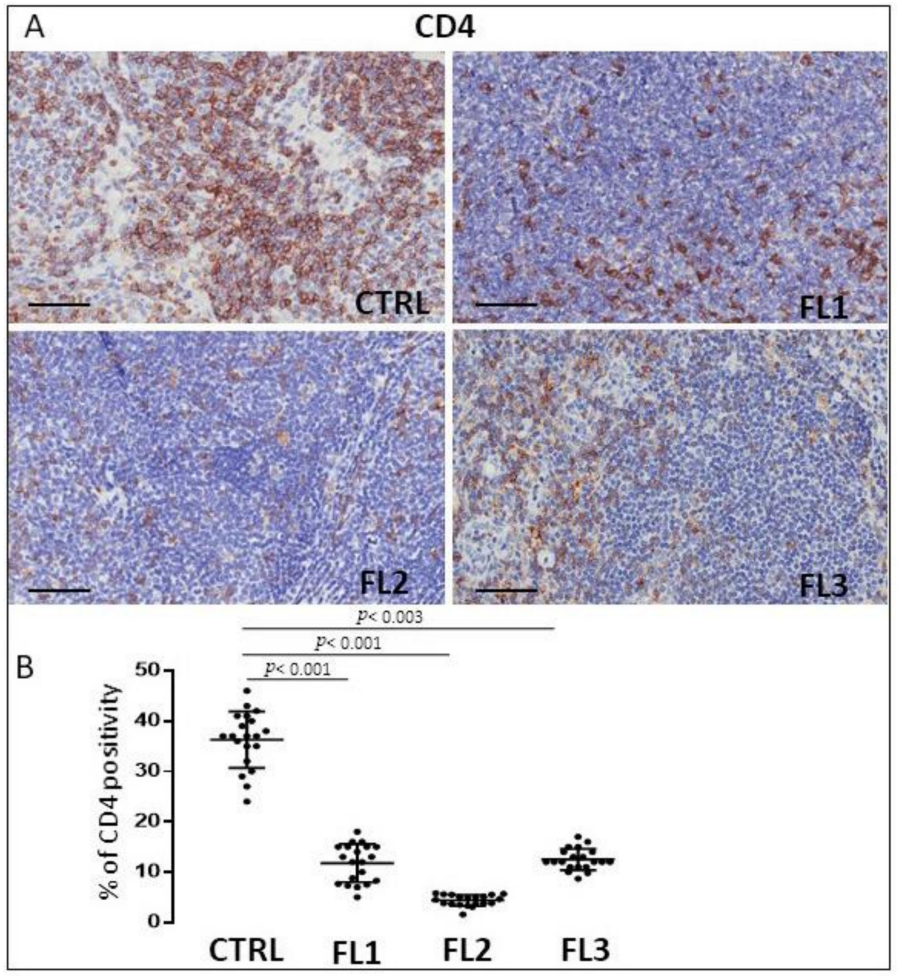

Figure 4. Immunohistochemical staining for CD4 in FL grade1 (FL1), FL grade2 (FL2), and FL grade 3 (FL3) and control samples (CTRL). Scale bar: $60 \mu \mathrm{m}$ (A). Morphometric analysis indicates the percentage of CD4 positivity in FL and CTRL samples (B). 


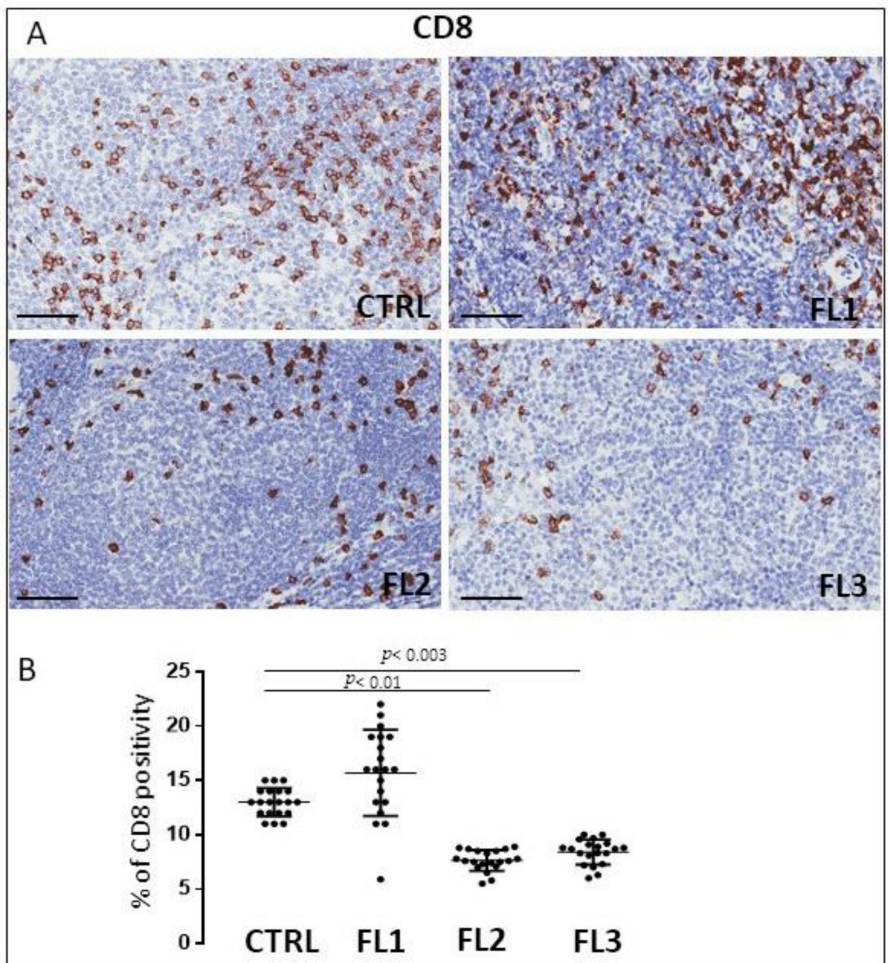

Figure 5. Immunohistochemical staining for CD8 in FL grade1 (FL1), FL grade2 (FL2), and FL grade 3 (FL3) and control samples (CTRL). Scale bar: $60 \mu \mathrm{m}$ (A). Morphometric analysis indicates the percentage of CD8 positivity in FL and CTRL samples (B).

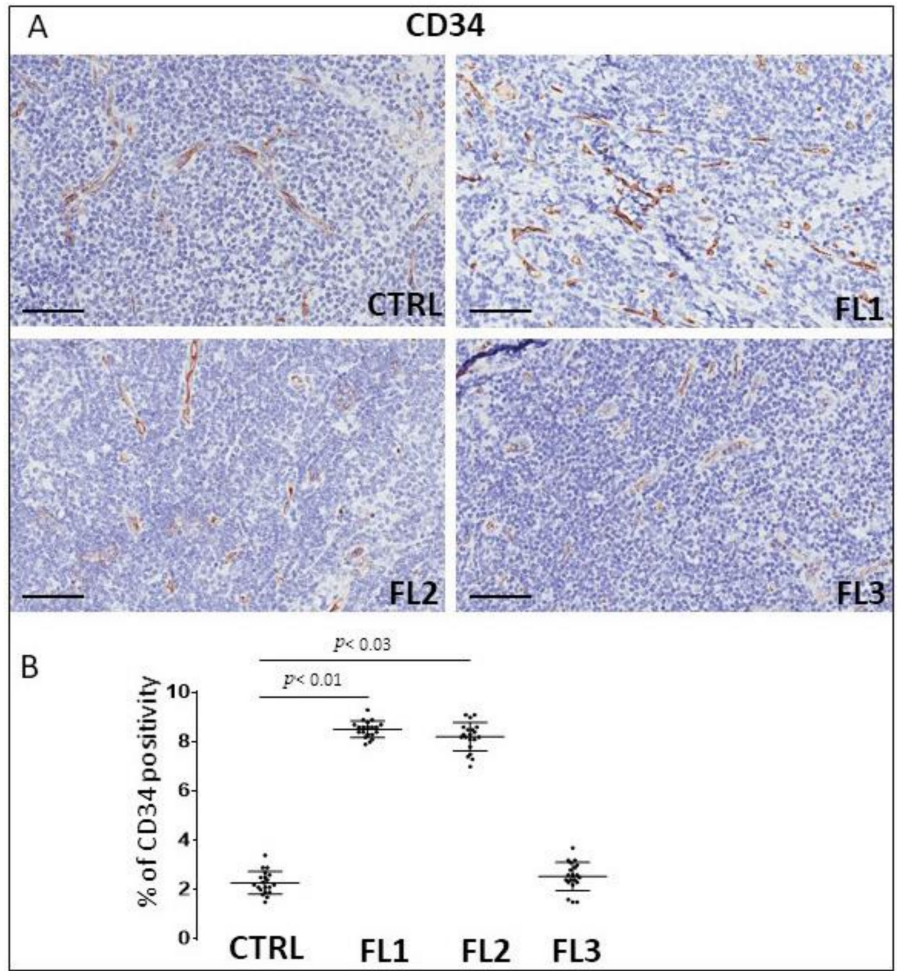

Figure 6. Immunohistochemical staining for CD34 in FL grade1 (FL1), FL grade2 (FL2), and FL grade 3 (FL3) and control samples (CTRL). Scale bar: $60 \mu \mathrm{m}$ (A). Morphometric analysis indicates the percentage of CD34 positivity in FL and CTRL samples (B). 


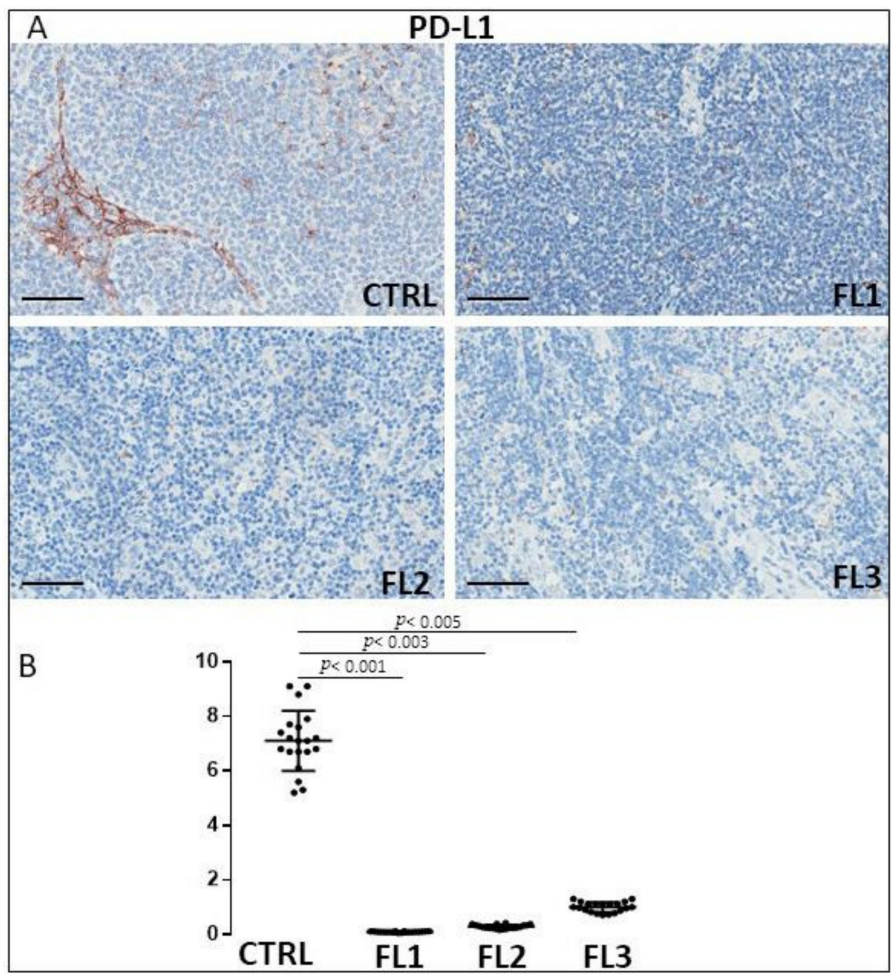

Figure 7. Immunohistochemical staining for PDL-1 in FL grade1 (FL1), FL grade2 (FL2), and FL grade 3 (FL3) and control samples (CTRL). Scale bar: $60 \mu \mathrm{m}$ (A). Morphometric analysis indicates the percentage of PDL-1 positivity in FL and CTRL samples (B).

\subsection{Correlation Analysis}

A positive correlation between CD68 and CD34 (rho $=0.52, p=0.0001$ ) and CD34 and CD163 (rho $=0.63, p=0.0001$ ) in the FL and CTRL groups (Figure 8) was found by Spearman correlation analysis.

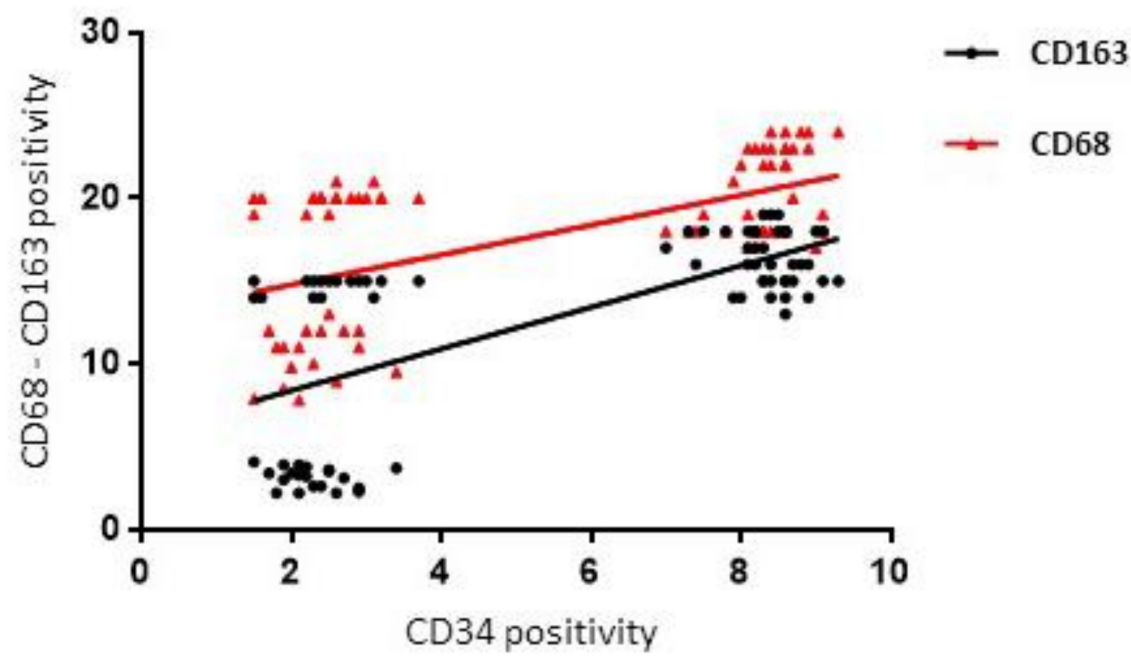

Figure 8. Regression analysis graph indicating the correlation between CD163 and CD34, CD68 and CD34 in FL and CTRL samples.

No correlation was established between CD68, CD163, tryptase, CD4, CD8, CD34, PDL-1, and FLIPI (\%) staging in FL patients 


\section{Discussion}

In this work, we quantified by immunohistochemistry the inflammatory cell content and the microvessel density in tissue samples derived from the lymph nodes of FL patients at grades 1,2, and 3A as compared with normal lymph nodes with the aim to establish a correlation with tumor progression. We selected patients with follicular growth patterns excluding the diffuse forms of FL in which the amount of interfollicular tissue is extremely variable and often absent, causing the back-to-back arrangement of follicles [44]. For this reason, we focused our analysis on the description of the characteristics of the follicular tumor tissue.

There is no effective therapy for $\mathrm{FL}$, and after the considerable prognosis improvement with the introduction of the monoclonal anti-CD-20 antibody (rituximab) more than 20 years ago, FL prognosis has not undergone any substantial changes [45-47]. This is due to the marked heterogeneity of this tumor, which depends, in part, on the different characteristics of cellular infiltrate in the TME. The FL microenvironment is composed of tumor-infiltrating $\mathrm{CD} 8^{+} \mathrm{T}$ cells, follicular regulatory and helper $\mathrm{CD} 4^{+} \mathrm{T}$ cells, TAMs and mast cells, follicular dendritic cells, and reticular cells, all involved in the regulation of the prognosis and progression of FL.

TAMs are involved in tumor growth, angiogenesis, metastasis, and immunosuppression in different types of lymphomas [48]. In particular, the association between TAMs and survival in FL progression is still controversial [49-52]. Kridel et al. reported that the increased $\mathrm{CD}_{163}{ }^{+}$cells were predictive of adverse or favorable FL outcomes dependent on R-CVP, or R-CHOP/R-maintenance treatment received [52]. Additionally, Dave et al. demonstrated that the downregulation of genes related to macrophage function predicts a favorable outcome [51]. Canioni and collaborators observed that patients with a high number of TAMs presented a significantly reduced event-free survival [50]. Some authors considered CD68 immunostaining as a useful routine tool in the prediction of the outcome of FL patients with a high tumor burden who receive chemotherapy [53]. In this study, we demonstrated an increased number of $\mathrm{CD} 68^{+}$and $\mathrm{CD} 163^{+}$TAMs in FL grade 1 which remains constant in 2 and $3 \mathrm{~A}$ of FL samples with respect to the normal lymph nodes.

Cancer progression is strongly influenced by the crosstalk between the tumor cells and inflammatory cells and both are associated with angiogenesis [54]. An increased number of blood vessels indicate a poor prognosis and low rate of survival in FL and clinicpathological data indicate angiogenesis as a target for therapy [55]. In FL patients with heterogeneous treatments, the increased interfollicular microvascular density predicted inferior overall survival (OS) and increased transformation to DLBCL [56]. These findings suggest that microvascular density may provide a rationale for trials with anti-angiogenic molecules in FL patients with increased microvascular density [55,57]. Our observations indicate an increase of microvascular density in grades 1 and 2 of FL samples as compared to the controls. The positive correlation between the increase of TAMs and microvascular density confirms the pro-angiogenic role played by TAMs in the tumor microenvironment of lymphomas [58,59]. Mast cells have a crucial role in tumor angiogenesis $[18,55,60]$, and their number is increased in bone marrow [61] and lymph node biopsies of NHL patients [62]. High mast cell counts interfere with the outcome of immune-chemo-therapytreated FL patients [49], and the adverse prognostic significance of MCs was demonstrated both in the treated patients and patients at diagnosis [63]. Our findings indicate that the tryptase $\mathrm{e}^{+}$mast cell number resulted in an increase only in the grade1 of FL samples, whereas in grades 2 and $3 \mathrm{~A}$, their number decreased with respect to the controls. We did not find a correlation between the microvascular density and mast cell numbers in FL. A high number of $\mathrm{CD}^{+} \mathrm{T}$ cells has been correlated to good prognosis $[64,65]$ and a high number of $\mathrm{CD}^{+} \mathrm{T}$ cells to poor prognosis in FL $[66,67]$, even if the prognostic importance of $\mathrm{T}$ cells infiltration seems to be modified by the therapy $[65,68]$. Our data indicated a reduction of $\mathrm{CD}^{+}$cells in all three FL grades with respect to the controls. Concerning $\mathrm{CD} 8^{+}$ cells, their numbers resulted in an increase in grades 2 and $3 \mathrm{~A}$ of FL with respect to the controls, whereas in grade 1 , the $\mathrm{CD} 8^{+}$number did not significantly increase with respect 
to the controls. The decrease of the $\mathrm{CD} 4 / \mathrm{CD} 8$ ratio could contribute to tumor angiogenesis and immune evasion during the late FL stages, as we have previously demonstrated in DLBCL and in MZL, where a positive correlation between the decreased CD4/CD8 ratio and microvessel density was established [16,18]. PD-1 [69] signaling induces the inhibition of T cells after ligation with PD-1 ligands (PD-Ls) such as PD-L1 [70,71] or PD-L2 [72], on neoplastic cells and in the tumor microenvironment. PD-L1 expression has been associated with clinical response to a PD-1 blockade in many clinical trials. Most FL tumor cells do not express PD-L1 or PD-L2 [73,74], however, PD- $1^{+}$cells are abundant in the TME of FL [73] and include $\mathrm{T}$ cells and follicular helper $\mathrm{T}$ cells from lymphomatous follicles or residual germinal centers [75]. In our study, we observed a significantly reduced presence of PD-L1 ${ }^{+}$ cells in all the grades of analyzed FL samples.

\section{Concluding Remarks}

Our study has shown an increased number of $\mathrm{CD}^{+} 8^{+}$and $\mathrm{CD} 163^{+}$TAMs in FL grade 1 which remains constant in 2 and $3 \mathrm{~A}$ of FL samples with respect to the controls and an increase of microvascular density in grades 1 and 2 of FL samples as compared to the controls. The positive correlation between the increase of TAMs and microvascular density confirms the pro-angiogenic role played by TAMs in the tumor microenvironment of lymphomas. Concerning mast cells, our findings indicate that the tryptase ${ }^{+}$mast cell number resulted in an increase only in grade 1 of FL samples, whereas in grades 2 and $3 \mathrm{~A}$, their number decreased with respect to the controls; we did not find a correlation between microvascular density and mast cell number. Concerning $\mathrm{T}$ cells, our data indicated a reduction of $\mathrm{CD} 4^{+}$ cells in all the three FL grades with respect to the controls, whereas the number of CD8 ${ }^{+}$ cells resulted in an increase in grades 2 and 3A of FL with respect to the controls; additionally, the decrease of the CD4/CD8 ratio could contribute to tumor angiogenesis and immune evasion during the late FL stages. Finally, we observed a significantly reduced number of PD-L1 ${ }^{+}$cells in all the grades of analyzed FL samples, establishing an inverse relationship between the number of PD-L1 ${ }^{+}$cells and tumor progression in FL.

Overall, these data confirm that the increase in TAM infiltration in FL lymph nodes is correlated with the increased microvascular density, underlying the crucial role played by these cells in lymphoma TME. Over the last 30 years, the importance of angiogenesis in human lymphoma has become well recognized, and several factors involved in its control are being identified. Anti-angiogenic therapy is an important tool for the treatment of human lymphoma. However, a significant number of patients are resistant, whereas those who respond have minimal benefits. Further research should provide new useful therapeutic approaches and increase options for patients with resistant or refractory disease. Finally, correlation analyses on a very large case series could provide results that would allow the development of new prognostic indexes significant for FL stratification.

Author Contributions: Writing original draft R.T. and D.R.; data curation T.A.; investigation T.P. and F.G.; review \& editing, G.I., G.S. and P.M. All authors have read and agreed to the published version of the manuscript.

Funding: This research received no external funding.

Acknowledgments: This work was supported by Associazione "Il Sorriso di Antonio," Corato, Italy, and Associazione Italiana Contro le Leucemie, Linfomi e Mielomi (AIL), Bari, Italy.

Conflicts of Interest: The authors declare no conflict of interest.

\section{References}

1. Campo, E.; Swerdlow, S.H.; Harris, N.L.; Pileri, S.; Stein, H.; Jaffe, E.S. The 2008 WHO classification of lymphoid neoplasms and beyond: Evolving concepts and practical applications. Blood 2011, 117, 5019-5032. [CrossRef]

2. Swerdlow, S.H.; Campo, E.; Pileri, S.A.; Harris, N.L.; Stein, H.; Siebert, R.; Advani, R.; Ghielmini, M.; Salles, G.A.; Zelenetz, A.D.; et al. The 2016 revision of the World Health Organization classification of lymphoid neoplasms. Blood 2016, 127, 2375-2390. [CrossRef] [PubMed] 
3. Batlevi, C.L.; Sha, F.; Alperovich, A.; Ni, A.; Smith, K.; Ying, Z.; Soumerai, J.D.; Caron, P.C.; Falchi, L.; Hamilton, A.; et al. Follicular lymphoma in the modern era: Survival, treatment outcomes, and identification of high-risk subgroups. Blood Cancer J. 2020, 10, 74. [CrossRef] [PubMed]

4. $\quad$ Leich, E.; Salaverria, I.; Bea, S.; Zettl, A.; Wright, G.; Moreno, V.; Gascoyne, R.D.; Chan, W.C.; Braziel, R.M.; Rimsza, L.M.; et al. Follicular lymphomas with and without translocation $\mathrm{t}(14 ; 18)$ differ in gene expression profiles and genetic alterations. Blood 2009, 114, 826-834. [CrossRef]

5. Mlynarczyk, C.; Fontan, L.; Melnick, A. Germinal center-derived lymphomas: The darkest side of humoral immunity. Immunol. Rev. 2019, 288, 214-239. [CrossRef]

6. Lamaison, C.; Tarte, K. B cell/stromal cell crosstalk in health, disease, and treatment: Follicular lymphoma as a paradigm. Immunol. Rev. 2021, 302, 273-285. [CrossRef] [PubMed]

7. Freedman, A. Follicular lymphoma: 2015 update on diagnosis and management. Am. J. Hematol. 2015, 90, 1171-1178. [CrossRef]

8. Rusconi, C.; Anastasia, A.; Chiarenza, A.; Marcheselli, L.; Cavallo, F.; Rattotti, S.; Botto, B.; Ferrari, A.; Nassi, L.; Pagani, C.; et al. Outcome of transformed follicular lymphoma worsens according to the timing of transformation and to the number of previous therapies. A retrospective multicenter study on behalf of Fondazione Italiana Linfomi (FIL). Br. J. Haematol. 2019, 185, 713-717. [CrossRef]

9. Kobayashi, T. The current therapeutic landscape for follicular lymphoma. Rinsho Ketsueki 2021, 62, 1070-1076.

10. Wahlin, B.E.; Sander, B.; Christensson, B.; Ostenstad, B.; Holte, H.; Brown, P.D.; Sundstrom, C.; Kimby, E. Entourage: The immune microenvironment following follicular lymphoma. Blood Cancer J. 2012, 2, e52. [CrossRef]

11. Inoue, H.; Rai, S.; Tanaka, H.; Espinoza, J.L.; Watatani, Y.; Kumode, T.; Serizawa, K.; Nakayama, S.; Taniguchi, Y.; Morita, Y.; et al. Tumour-immune microenvironment in duodenal-type follicular lymphoma. Br. J. Haematol. 2020, 191, 243-252. [CrossRef] [PubMed]

12. Dobano-Lopez, C.; Araujo-Ayala, F.; Serrat, N.; Valero, J.G.; Perez-Galan, P. Follicular Lymphoma Microenvironment: An Intricate Network Ready for Therapeutic Intervention. Cancers 2021, 13, 641. [CrossRef] [PubMed]

13. Townsend, W.; Pasikowska, M.; Yallop, D.; Phillips, E.H.; Patten, P.E.M.; Salisbury, J.R.; Marcus, R.; Pepper, A.; Devereux, S. The architecture of neoplastic follicles in follicular lymphoma; analysis of the relationship between the tumor and follicular helper $\mathrm{T}$ cells. Haematologica 2020, 105, 1593-1603. [CrossRef] [PubMed]

14. Solal-Celigny, P.; Roy, P.; Colombat, P.; White, J.; Armitage, J.O.; Arranz-Saez, R.; Au, W.Y.; Bellei, M.; Brice, P.; Caballero, D.; et al. Follicular lymphoma international prognostic index. Blood 2004, 104, 1258-1265. [CrossRef] [PubMed]

15. Tsakiroglou, A.M.; Astley, S.; Dave, M.; Fergie, M.; Harkness, E.; Rosenberg, A.; Sperrin, M.; West, C.; Byers, R.; Linton, K. Immune infiltrate diversity confers a good prognosis in follicular lymphoma. Cancer Immunol. Immunother. 2021, 70, 3573-3585. [CrossRef] [PubMed]

16. Tamma, R.; Ingravallo, G.; Gaudio, F.; Annese, T.; Albano, F.; Ruggieri, S.; Dicataldo, M.; Maiorano, E.; Specchia, G.; Ribatti, D. STAT3, tumor microenvironment, and microvessel density in diffuse large B cell lymphomas. Leuk. Lymphoma 2020, 61, 567-574. [CrossRef] [PubMed]

17. Tamma, R.; Ingravallo, G.; Annese, T.; De Giorgis, M.; Di Giovanni, F.; Gaudio, F.; Perrone, T.; Musto, P.; Specchia, G.; Ribatti, D. Tumor Cell Microenvironment and Microvessel Density Analysis in MALT Type Lymphoma. Anticancer Res. 2021, 41, $1291-1297$. [CrossRef]

18. Tamma, R.; Ranieri, G.; Ingravallo, G.; Annese, T.; Oranger, A.; Gaudio, F.; Musto, P.; Specchia, G.; Ribatti, D. Inflammatory Cells in Diffuse Large B Cell Lymphoma. J. Clin. Med. 2020, 9, 2418. [CrossRef]

19. Coussens, L.M.; Werb, Z. Inflammation and cancer. Nature 2002, 420, 860-867. [CrossRef]

20. Pathria, P.; Louis, T.L.; Varner, J.A. Targeting Tumor-Associated Macrophages in Cancer. Trends Immunol. 2019, 40, 310-327. [CrossRef]

21. Wang, J.; Li, D.; Cang, H.; Guo, B. Crosstalk between cancer and immune cells: Role of tumor-associated macrophages in the tumor microenvironment. Cancer Med. 2019, 8, 4709-4721. [CrossRef] [PubMed]

22. Rabenhorst, A.; Schlaak, M.; Heukamp, L.C.; Forster, A.; Theurich, S.; von Bergwelt-Baildon, M.; Buttner, R.; Kurschat, P.; Mauch, C.; Roers, A.; et al. Mast cells play a protumorigenic role in primary cutaneous lymphoma. Blood 2012, 120, 2042-2054. [CrossRef]

23. Franco, G.; Guarnotta, C.; Frossi, B.; Piccaluga, P.P.; Boveri, E.; Gulino, A.; Fuligni, F.; Rigoni, A.; Porcasi, R.; Buffa, S.; et al. Bone marrow stroma CD40 expression correlates with inflammatory mast cell infiltration and disease progression in splenic marginal zone lymphoma. Blood 2014, 123, 1836-1849. [CrossRef] [PubMed]

24. Maciel, T.T.; Moura, I.C.; Hermine, O. The role of mast cells in cancers. F1000Prime Rep. 2015, 7, 09. [CrossRef] [PubMed]

25. Laurent, C.; Muller, S.; Do, C.; Al-Saati, T.; Allart, S.; Larocca, L.M.; Hohaus, S.; Duchez, S.; Quillet-Mary, A.; Laurent, G.; et al. Distribution, function, and prognostic value of cytotoxic T lymphocytes in follicular lymphoma: A 3-D tissue-imaging study. Blood 2011, 118, 5371-5379. [CrossRef]

26. Liu, X.; Venkataraman, G.; Lin, J.; Kiyotani, K.; Smith, S.; Montoya, M.; Nakamura, Y.; Kline, J. Highly clonal regulatory T-cell population in follicular lymphoma-Inverse correlation with the diversity of CD8(+) T cells. Oncoimmunology 2015, 4, e1002728. [CrossRef]

27. Kiaii, S.; Clear, A.J.; Ramsay, A.G.; Davies, D.; Sangaralingam, A.; Lee, A.; Calaminici, M.; Neuberg, D.S.; Gribben, J.G. Follicular lymphoma cells induce changes in T-cell gene expression and function: Potential impact on survival and risk of transformation. J. Clin. Oncol. 2013, 31, 2654-2661. [CrossRef] 
28. Umetsu, D.T.; Esserman, L.; Donlon, T.A.; DeKruyff, R.H.; Levy, R. Induction of proliferation of human follicular (B type) lymphoma cells by cognate interaction with CD4+ T cell clones. J. Immunol. 1990, 144, 2550-2557.

29. Burack, W.R.; Spence, J.M.; Spence, J.P.; Spence, S.A.; Rock, P.J.; Shenoy, G.N.; Shultz, L.D.; Bankert, R.B.; Bernstein, S.H Patient-derived xenografts of low-grade B-cell lymphomas demonstrate roles of the tumor microenvironment. Blood Adv. 2017, 1, 1263-1273. [CrossRef]

30. Mondello, P.; Fama, A.; Larson, M.C.; Feldman, A.L.; Villasboas, J.C.; Yang, Z.Z.; Galkin, I.; Svelolkin, V.; Postovalova, E.; Bagaev, A.; et al. Lack of intrafollicular memory CD4 + T cells is predictive of early clinical failure in newly diagnosed follicular lymphoma Blood Cancer J. 2021, 11, 130. [CrossRef]

31. Strasly, M.; Cavallo, F.; Geuna, M.; Mitola, S.; Colombo, M.P.; Forni, G.; Bussolino, F. IL-12 inhibition of endothelial cell functions and angiogenesis depends on lymphocyte-endothelial cell cross-talk. J. Immunol. 2001, 166, 3890-3899. [CrossRef] [PubMed]

32. Lewis, C.E.; Harney, A.S.; Pollard, J.W. The Multifaceted Role of Perivascular Macrophages in Tumors. Cancer Cell 2016, 30, 18-25. [CrossRef] [PubMed]

33. DeNardo, D.G.; Barreto, J.B.; Andreu, P.; Vasquez, L.; Tawfik, D.; Kolhatkar, N.; Coussens, L.M. CD4(+) T cells regulate pulmonary metastasis of mammary carcinomas by enhancing protumor properties of macrophages. Cancer Cell 2009, 16, 91-102. [CrossRef] [PubMed]

34. Vinay, D.S.; Ryan, E.P.; Pawelec, G.; Talib, W.H.; Stagg, J.; Elkord, E.; Lichtor, T.; Decker, W.K.; Whelan, R.L.; Kumara, H.; et al Immune evasion in cancer: Mechanistic basis and therapeutic strategies. Semin. Cancer Biol. 2015, 35, S185-S198. [CrossRef] [PubMed]

35. Zhao, R.; Song, Y.; Wang, Y.; Huang, Y.; Li, Z.; Cui, Y.; Yi, M.; Xia, L.; Zhuang, W.; Wu, X.; et al. PD-1/PD-L1 blockade rescue exhausted CD8+ T cells in gastrointestinal stromal tumours via the PI3K/Akt/mTOR signalling pathway. Cell Prolif. 2019, 52, e12571. [CrossRef]

36. Mimura, K.; Teh, J.L.; Okayama, H.; Shiraishi, K.; Kua, L.F.; Koh, V.; Smoot, D.T.; Ashktorab, H.; Oike, T.; Suzuki, Y.; et al. PD-L1 expression is mainly regulated by interferon gamma associated with JAK-STAT pathway in gastric cancer. Cancer Sci. 2018, 109, 43-53. [CrossRef]

37. Yi, M.; Zhang, J.; Li, A.; Niu, M.; Yan, Y.; Jiao, Y.; Luo, S.; Zhou, P.; Wu, K. The construction, expression, and enhanced anti-tumor activity of YM101: A bispecific antibody simultaneously targeting TGF-beta and PD-L1. J. Hematol. Oncol. 2021, 14, 27. [CrossRef]

38. Chu, Y.; Zhou, X.; Wang, X. Antibody-drug conjugates for the treatment of lymphoma: Clinical advances and latest progress. J. Hematol. Oncol. 2021, 14, 88. [CrossRef]

39. Wight, J.C.; Hawkes, E.A.; Berlangieri, S.U.; Khor, R.; Grigg, A.P. An abscopal effect may augment PD-1 inhibition in refractory classical Hodgkin lymphoma. Leuk. Lymphoma 2018, 59, 2749-2751. [CrossRef]

40. Zhang, J.; Medeiros, L.J.; Young, K.H. Cancer Immunotherapy in Diffuse Large B-Cell Lymphoma. Front. Oncol. $2018,8,351$. [CrossRef]

41. Lesokhin, A.M.; Ansell, S.M.; Armand, P.; Scott, E.C.; Halwani, A.; Gutierrez, M.; Millenson, M.M.; Cohen, A.D.; Schuster, S.J.; Lebovic, D.; et al. Nivolumab in Patients with Relapsed or Refractory Hematologic Malignancy: Preliminary Results of a Phase Ib Study. J. Clin. Oncol. 2016, 34, 2698-2704. [CrossRef] [PubMed]

42. Ansell, S.M.; Hurvitz, S.A.; Koenig, P.A.; LaPlant, B.R.; Kabat, B.F.; Fernando, D.; Habermann, T.M.; Inwards, D.J.; Verma, M.; Yamada, R.; et al. Phase I study of ipilimumab, an anti-CTLA-4 monoclonal antibody, in patients with relapsed and refractory B-cell non-Hodgkin lymphoma. Clin. Cancer Res. 2009, 15, 6446-6453. [CrossRef]

43. Westin, J.R.; Chu, F.; Zhang, M.; Fayad, L.E.; Kwak, L.W.; Fowler, N.; Romaguera, J.; Hagemeister, F.; Fanale, M.; Samaniego, F.; et al. Safety and activity of PD1 blockade by pidilizumab in combination with rituximab in patients with relapsed follicular lymphoma: A single group, open-label, phase 2 trial. Lancet Oncol. 2014, 15, 69-77. [CrossRef]

44. Maskey, N.; Chen, Q.; Liu, F.; Liu, S.; Tian, S. A rare face of follicular lymphoma: Reverse variant of follicular lymphoma. Diagn. Pathol. 2020, 15, 31. [CrossRef] [PubMed]

45. Freedman, A. Follicular lymphoma: 2018 update on diagnosis and management. Am. J. Hematol. 2018, 93, 296-305. [CrossRef] [PubMed]

46. Horning, S.J. Natural history of and therapy for the indolent non-Hodgkin's lymphomas. Semin. Oncol. 1993, 20, 75-88. [PubMed]

47. Grillo-Lopez, A.J.; White, C.A.; Dallaire, B.K.; Varns, C.L.; Shen, C.D.; Wei, A.; Leonard, J.E.; McClure, A.; Weaver, R.; Cairelli, S.; et al. Rituximab: The first monoclonal antibody approved for the treatment of lymphoma. Curr. Pharm. Biotechnol. 2000, 1, 1-9. [CrossRef]

48. Pham, L.V.; Pogue, E.; Ford, R.J. The Role of Macrophage/B-Cell Interactions in the Pathophysiology of B-Cell Lymphomas. Front. Oncol. 2018, 8, 147. [CrossRef]

49. Taskinen, M.; Karjalainen-Lindsberg, M.L.; Leppa, S. Prognostic influence of tumor-infiltrating mast cells in patients with follicular lymphoma treated with rituximab and CHOP. Blood 2008, 111, 4664-4667. [CrossRef]

50. Canioni, D.; Salles, G.; Mounier, N.; Brousse, N.; Keuppens, M.; Morchhauser, F.; Lamy, T.; Sonet, A.; Rousselet, M.C.; Foussard, C.; et al. High numbers of tumor-associated macrophages have an adverse prognostic value that can be circumvented by rituximab in patients with follicular lymphoma enrolled onto the GELA-GOELAMS FL-2000 trial. J. Clin. Oncol. 2008, 26, 440-446. [CrossRef]

51. Dave, S.S.; Wright, G.; Tan, B.; Rosenwald, A.; Gascoyne, R.D.; Chan, W.C.; Fisher, R.I.; Braziel, R.M.; Rimsza, L.M.; Grogan, T.M.; et al. Prediction of survival in follicular lymphoma based on molecular features of tumor-infiltrating immune cells. N. Engl. J. Med. 2004, 351, 2159-2169. [CrossRef] [PubMed] 
52. Kridel, R.; Xerri, L.; Gelas-Dore, B.; Tan, K.; Feugier, P.; Vawda, A.; Canioni, D.; Farinha, P.; Boussetta, S.; Moccia, A.A.; et al. The Prognostic Impact of CD163-Positive Macrophages in Follicular Lymphoma: A Study from the BC Cancer Agency and the Lymphoma Study Association. Clin. Cancer Res. 2015, 21, 3428-3435. [CrossRef] [PubMed]

53. Andjelic, B.; Mihaljevic, B.; Todorovic, M.; Bila, J.; Jakovic, L.; Jovanovic, M.P. The number of lymphoma-associated macrophages in tumor tissue is an independent prognostic factor in patients with follicular lymphoma. Appl. Immunohistochem. Mol. Morphol. 2012, 20, 41-46. [CrossRef] [PubMed]

54. Ruan, J.; Hajjar, K.; Rafii, S.; Leonard, J.P. Angiogenesis and antiangiogenic therapy in non-Hodgkin's lymphoma. Ann. Oncol. 2009, 20, 413-424. [CrossRef] [PubMed]

55. Farinha, P.; Kyle, A.H.; Minchinton, A.I.; Connors, J.M.; Karsan, A.; Gascoyne, R.D. Vascularization predicts overall survival and risk of transformation in follicular lymphoma. Haematologica 2010, 95, 2157-2160. [CrossRef] [PubMed]

56. Jorgensen, J.M.; Sorensen, F.B.; Bendix, K.; Nielsen, J.L.; Olsen, M.L.; Funder, A.M.; d'Amore, F. Angiogenesis in non-Hodgkin's lymphoma: Clinico-pathological correlations and prognostic significance in specific subtypes. Leuk. Lymphoma 2007, 48, 584-595. [CrossRef] [PubMed]

57. Crivellato, E.; Nico, B.; Vacca, A.; Ribatti, D. Ultrastructural analysis of mast cell recovery after secretion by piecemeal degranulation in B-cell non-Hodgkin's lymphoma. Leuk. Lymphoma 2003, 44, 517-521. [CrossRef]

58. Marinaccio, C.; Ingravallo, G.; Gaudio, F.; Perrone, T.; Nico, B.; Maoirano, E.; Specchia, G.; Ribatti, D. Microvascular density, CD68 and tryptase expression in human diffuse large B-cell lymphoma. Leuk. Res. 2014, 38, 1374-1377. [CrossRef]

59. Jayasingam, S.D.; Citartan, M.; Thang, T.H.; Mat Zin, A.A.; Ang, K.C.; Ch'ng, E.S. Evaluating the Polarization of Tumor-Associated Macrophages into M1 and M2 Phenotypes in Human Cancer Tissue: Technicalities and Challenges in Routine Clinical Practice. Front. Oncol. 2019, 9, 1512. [CrossRef]

60. Maltby, S.; Khazaie, K.; McNagny, K.M. Mast cells in tumor growth: Angiogenesis, tissue remodelling and immune-modulation. Biochim. Biophys. Acta 2009, 1796, 19-26. [CrossRef]

61. Wilkins, B.S.; Buchan, S.L.; Webster, J.; Jones, D.B. Tryptase-positive mast cells accompany lymphocytic as well as lymphoplasmacytic lymphoma infiltrates in bone marrow trephine biopsies. Histopathology 2001, 39, 150-155. [CrossRef] [PubMed]

62. Ribatti, D.; Nico, B.; Vacca, A.; Marzullo, A.; Calvi, N.; Roncali, L.; Dammacco, F. Do mast cells help to induce angiogenesis in B-cell non-Hodgkin's lymphomas? Br. J. Cancer 1998, 77, 1900-1906. [CrossRef] [PubMed]

63. Duse, A.O.; Ceausu, R.A.; Mezei, T.; Cimpean, A.M.; Gaje, P.; Ionita, H.; Jung, I. Mast cells contribute to the angiogenesis in non-Hodgkin lymphoma. An immunohistochemical study based on the relationship with microvessel density. Rom. J. Morphol. Embryol. 2011, 52 (Suppl. 3), 1091-1096. [PubMed]

64. Alvaro, T.; Lejeune, M.; Salvado, M.T.; Lopez, C.; Jaen, J.; Bosch, R.; Pons, L.E. Immunohistochemical patterns of reactive microenvironment are associated with clinicobiologic behavior in follicular lymphoma patients. J. Clin. Oncol. 2006, 24, 5350-5357. [CrossRef] [PubMed]

65. Wahlin, B.E.; Sander, B.; Christensson, B.; Kimby, E. CD8+ T-cell content in diagnostic lymph nodes measured by flow cytometry is a predictor of survival in follicular lymphoma. Clin. Cancer Res. 2007, 13 Pt 1, 388-397. [CrossRef]

66. Lee, A.M.; Clear, A.J.; Calaminici, M.; Davies, A.J.; Jordan, S.; MacDougall, F.; Matthews, J.; Norton, A.J.; Gribben, J.G.; Lister, T.A.; et al. Number of CD4+ cells and location of forkhead box protein P3-positive cells in diagnostic follicular lymphoma tissue microarrays correlates with outcome. J. Clin. Oncol. 2006, 24, 5052-5059. [CrossRef]

67. Byers, R.J.; Sakhinia, E.; Joseph, P.; Glennie, C.; Hoyland, J.A.; Menasce, L.P.; Radford, J.A.; Illidge, T. Clinical quantitation of immune signature in follicular lymphoma by RT-PCR-based gene expression profiling. Blood 2008, 111, 4764-4770. [CrossRef]

68. De Jong, D.; Koster, A.; Hagenbeek, A.; Raemaekers, J.; Veldhuizen, D.; Heisterkamp, S.; de Boer, J.P.; van Glabbeke, M. Impact of the tumor microenvironment on prognosis in follicular lymphoma is dependent on specific treatment protocols. Haematologica 2009, 94, 70-77. [CrossRef]

69. Ishida, Y.; Agata, Y.; Shibahara, K.; Honjo, T. Induced expression of PD-1, a novel member of the immunoglobulin gene superfamily, upon programmed cell death. EMBO J. 1992, 11, 3887-3895. [CrossRef]

70. Freeman, G.J.; Long, A.J.; Iwai, Y.; Bourque, K.; Chernova, T.; Nishimura, H.; Fitz, L.J.; Malenkovich, N.; Okazaki, T.; Byrne, M.C.; et al. Engagement of the PD-1 immunoinhibitory receptor by a novel B7 family member leads to negative regulation of lymphocyte activation. J. Exp. Med. 2000, 192, 1027-1034. [CrossRef]

71. Dong, H.; Zhu, G.; Tamada, K.; Chen, L. B7-H1, a third member of the B7 family, co-stimulates T-cell proliferation and interleukin10 secretion. Nat. Med. 1999, 5, 1365-1369. [CrossRef] [PubMed]

72. Latchman, Y.; Wood, C.R.; Chernova, T.; Chaudhary, D.; Borde, M.; Chernova, I.; Iwai, Y.; Long, A.J.; Brown, J.A.; Nunes, R.; et al. PD-L2 is a second ligand for PD-1 and inhibits T cell activation. Nat. Immunol. 2001, 2, 261-268. [CrossRef] [PubMed]

73. Laurent, C.; Charmpi, K.; Gravelle, P.; Tosolini, M.; Franchet, C.; Ysebaert, L.; Brousset, P.; Bidaut, A.; Ycart, B.; Fournie, J.J. Several immune escape patterns in non-Hodgkin's lymphomas. Oncoimmunology 2015, 4, e1026530. [CrossRef] [PubMed]

74. Menter, T.; Bodmer-Haecki, A.; Dirnhofer, S.; Tzankov, A. Evaluation of the diagnostic and prognostic value of PDL1 expression in Hodgkin and B-cell lymphomas. Hum. Pathol. 2016, 54, 17-24. [CrossRef] [PubMed]

75. Myklebust, J.H.; Irish, J.M.; Brody, J.; Czerwinski, D.K.; Houot, R.; Kohrt, H.E.; Timmerman, J.; Said, J.; Green, M.R.; Delabie, J.; et al. High PD-1 expression and suppressed cytokine signaling distinguish T cells infiltrating follicular lymphoma tumors from peripheral T cells. Blood 2013, 121, 1367-1376. [CrossRef] 